\title{
ANALISIS REVIEW KELENGKAPAN FORMULIR RINGKASAN PULANG DALAM PEMENUHAN ELEMEN PENILAIAN MIRM 15 SNARS EDISI 1 DI RUMAH SAKIT MUHAMMADIYAH SELOGIRI
}

\author{
Febri Sri Mardeni ${ }^{1 *}$, Fahmi Hakam², Yul Asriati ${ }^{3}$ \\ $1 *$ RS Muhammadiyah Selogiri, ${ }^{2,3}$ Universitas Veteran Bangun Nusantara \\ *Email :febrimardeni88@gmail.com
}

\begin{abstract}
The incompleteness in filling out medical records will greatly affect the SNARS 1st edition accreditation assessment.The results of the assessment from the Hospital Accreditation Committee survey of the MIRM 15 standard at Muhammadiyah Selogiri Hospital, namely the summary of going home with the completion level of filling in 2019 has not reached the 100\% standard. The purpose of this study was to review the completeness of the return summary form in fulfilling the elements of the MIRM 15 SNARS 1st edition assessment at the Muhammadiyah Hospital Selogiri. This research used a descriptive research method, with a qualitative approach, the data collection method used observation, interviews, documentation study with the subject of 4 officers, the object was all documents of inpatients in February 2020 totaling 571 documents. The survey results revealed the completeness of the summary forms return in February at the reviews of identification of $100 \%$, review authentication $81 \%$, Review of recording by $64 \%$, reviews reporting in accordance SNARS element 1 are met incomplete, element 2 is fulfilled complete, the element 3 is met, the elements 4 are met complete, element 5 is fulfilled completely, element 6 is partially fulfilled. The conclusion of this study is that the level of completeness of the summary form home at Muhammadiyah Selogiri Hospital in February 2020 is not according to the standard, namely $11 \%$.
\end{abstract}

Keywords: SNARS1 st edition, MIRM15, copleteness of the return summary form.

\begin{abstract}
ABSTRAK
Ketidaklengkapan dalam pengisian rekam medis akan sangat mempengaruhi dalam penilaian akreditasi SNARS Edisi 1. Hasil penilaian dari survey Komite Akreditasi Rumah Sakit tentang standar MIRM 15 di RS Muhammadiyah Selogiri yaitu ringkasan pulang dengan tingkat kelengkapan pengisian tahun 2019 belum mencapai standar 100\%. Tujuan dari penelitian ini adalah review kelengkapan formulir ringkasan pulang dalam pemenuhan elemen penilaian MIRM 15 SNARS edisi 1 di rumah sakit muhammadiyah selogiri. Penelitian ini menggunakan metode penelitian deskriptif, dengan pendekatan kualitatif, metode pengumpulan data menggunakan observasi, wawancara, studi dokumentasi dengan subjek 4 petugas, objek yaitu seluruh dokumen pasien rawat inap bulan Februari tahun 2020 sebesar 571 dokumen. Hasil penelitian diketahui kelengkapan pada formulir ringkasan pulang bulan Februari review identifikasi 100\%, review autentifikasi $81 \%$, Review pencatatan sebesar $64 \%$, review pelaporan sesuai SNARS elemen 1 terpenuhi lengkap, elemen 2 terpenuhi lengkap, elemen 3 terpenuhi sebagian, elemen 4 terpenuhi lengkap, elemen 5 terpenuhi lengkap, elemen 6 terpenuhi sebagian. Kesimpulan dari penelitian ini yaitu tingkat kelengkapan formulir ringkasan pulang di RS Muhammadiyah Selogiri pada bulan Februari 2020 belum sesuai standar yaitu sebesar $11 \%$.
\end{abstract}

Kata kunci: SNARS Edisi1, MIRM15, kelengkapan formulir ringkasan pulang. 


\section{PENDAHULUAN}

Berdasarkan Peraturan Menteri Kesehatan No. 56 Tahun 2014, tentang Klasifikasi dan Perizinan Rumah Sakit pada Pasal 76 disebutkan bahwa setiap rumah sakit yang telah mendapatkan izin operasional harus diregistrasi dan diakreditasi sebagai persyaratan untuk perpanjangan izin operasional dan perubahan kelas.

Dengan ditetapkannya Undang - Undang Kesehatan Nomor 36 tahun 2009 tentang Kesehatan dan Undang - Undang Nomor 44 tahun 2009 tentang Rumah Sakit maka Rekam medis menjadi salah satu kewajiban pencatatan sebagai Informasi pasien yang harus diselenggarakan oleh rumah sakit dengan baik dan benar dan telah diatur dalam Peraturan Menteri Kesehatan Republik Indonesia Nomor 269/Menkes/Per/III/2008 tentang Rekam Medis. Rekam medis harus dibuat segera dan dilengkapi setelah pasien menerima pelayanan. Setiap pencatatan ke dalam rekam medis harus dibubuhi nama, waktu dan tanda tangan dokter, dokter gigi atau tenaga kesehatan tertentu yang memberikan pelayanan kesehatan secara langsung (Permenkes No. 269/ MenKes/ Per/III/2008). Bentuk pencatatan dokumen Rekam Medis salah satunya adalah Ringkasan Pulang (discharge summary). Menurut Hatta (2010), resume (ringkasan pulang) adalah ringkasan seluruh masa perawatan dan pengobatan yang dilakukan para tenaga kesehatan kepada pasien, yang memuat informasi tentang jenis perawatan terhadap pasien, reaksi tubuh terhadap pengobatan, kondisi pada saat pulang dan tindak lanjut pengobatan setelah pasien pulang.

Pasal 40 ayat (1) UU nomor 44 tahun 2009 juga menyebut bahwa dalam upaya meningkatkan mutu pelayanan rumah sakit wajib dilakukan akreditasi secara berkala minimal tiga tahun sekali. Standar Nasional Akreditasi Rumah Sakit Edisi 1 yang selanjutnya disebut SNARS Edisi 1 ini juga dijelaskan bagaimana penyusunan, penambahan Bab penting pada SNARS Edisi 1 ini, referensi dari setiap bab dan juga kebijakan pelaksanaan akreditasi rumah sakit. (KARS, 2017). Penyelenggaraan Rekam Medis dalam SNARS Edisi 1 masuk dalam kelompok Standar Manajemen Rumah Sakit tentang Manajemen Informasi dan Rekam Medis (MIRM), yang terdiri dari 15 elemen penilaian. (Harjanti and
Rizka, 2019). Pada standar MIRM yang berfokus pada rekam medis yaitu MIRM 8 sampai 15. Standar MIRM meliputi organisasi dan manajemen, akses serta penyimpanan RM, dan RM pasien. Sesuai dengan standar akreditasi rumah sakit, sebagai bagian peningkatan kinerja, rumah sakit secara teratur melakukan penilaian terhadap isi dan kelengkapan berkas rekam medis pasien, khususnya lembar ringkasan pulang yang terdapat pada MIRM 15.

Berdasarkan hasil studi pendahuluan di RS Muhammadiyah Selogiri, bahwa hasil penilaian dari survey Komite Akreditasi Rumah Sakit tentang standar MIRM 15 di RS Muhammadiyah Selogiri yaitu ringkasan pulang yang telah dikerjakan belum lengkap,dan mendapatkan rekomendasi paling banyak dari surveyor dibandingkan elemen penilainya lainnya, sedangkan score penilaian MIRM 15 yaitu 5 dari grade penilaian 0,5, dan 10 .

Kelengkapan pengisian berkas ringkasan pulang sangatlah penting, karena selain masuk dalam elemen penilaian akreditasi SNARS Edisi 1, dengan tidak lengkapnya pengisian formulir ringkasan pulang juga dapat mempengaruhi proses klaim BPJS kesehatan yang berakibat rumah sakit tidak mendapatkan penggantian biaya operasional perawatan pasien dari BPJS dan mempengaruhi mutu RS. Dari latar belakang diatas, maka peneliti akan melakukan penelitian untuk menganalisa kelengkapan pengisian ringkasan pulang sehingga apakah telah terpenenuhi dalam menunjang proses penilaian MIRM 15 SNARS Edisi-1 pada persiapan resurvey akreditasi di Rumah Sakit Muhammadiyah Selogiri.

Tujuan dari penelitian ini adalah menganalisa review kelengkapan formulir ringkasan pulang dalam pemenuhan elemen penilaian mirm 15 snars edisi 1 di rumah sakit muhammadiyah selogiri. 


\section{METODOLOGI PENELITIAN}

Desain penelitian ini adalah deskriptif, dengan pendekatan kualitatif. Peneliti melakukan penelitian deskriptif untuk menggambarkan atau mendeskriptifkan kelengkapan pengisian formulir ringkasan pulang dan faktor-faktor yang mempengaruhi tingkat ketidaklengkapan formulir ringkasan pulang di RS Muhammadiyah Selogiri. Subjek dalam penelitian ini ada 4 orang yang terdiri dari 1 Kepala Rekam Medis, 1 dokter penanggungjawab pelayanan, 1 kepala bangsala perawat dan 1 perawat pelaksana dan objek dalam penelitian ini terdiri dari 571 dokumen rekam medis rawat inap bulan Februari tahun 2020 di RS Muhammadiyah Selogiri.

\section{HASIL PENELITIAN}

Hasil review kelengkapan yang terdiri dari review identifikasi, autentifikasi, dan pencatatan.

Komponen review kelengkapan meliputi review identifikasi, autentifikasi dan pencatatan. Pada gambar 4.1 dapat diketahui dari 571 formulir ringkasan pulang review identifikasi yang terdiri dari nama dan tanggal lahir yaitu $100 \%$, review autentifikasi kelengkapan terdiri dari tanda tangan pasien/ keluarga dan tanda tangan dokter DPJP presentase sebanyak 590 $(86 \%)$, tidak lengkap yaitu $81(14 \%)$. Review pencatatan terdiri dari ada tidaknya coretan pada penulisan yang sesuai dengan ketentuan serta keterbacaan penulisan yaitu tingkat kelengkapan sebanyak $367(64 \%)$ dan tidak lengkap 204 $(36 \%)$. Hasil wawancara dengan kepala bangsal perawatan, perawat pelaksana dan DPJP diantaranya adalah karena pasien menghendaki pulang permintaan sendiri saat dokter belum visite mengakibatkan tanda tangan DPJP masih kosong dan pasien meninggal saat dokter tidak berada di rumah sakit juga mengakibatkan tanda tangan DPJP masih kosong.

\section{Hasil review pelaporan sesuai penilaian akreditasi standar MIRM 15 elemen 1 Snars Edisil}

Komponen review pelaporan elemen 1 Snars Edisi 1 meliputi riwayat kesehatan, pemeriksaan fisik dan pemeriksaan diagnostik. Pada item riwayat kesehatan, pemeriksaan fisik kelengkapan sebanyak 555 (97\%) formulir ringkasan pulang,dan tidak lengkap yaitu 16 (3\%) formulir ringkasan pulang. Pada item pemeriksaan diagnostik sebanyak 492 (86\%) formulir ringkasan pulang dan yang tidak lengkap yaitu 79 (14\%).
Hasil Review pelaporan sesuai penilaian akreditasi standar MIRM 15 elemen 2 Snars Edisi 1

Komponen review pelaporan elemen 2 MIRM 15 Snars Edisi 1 meliputi indikasi pasien dirawat inap, diagnosis dan komobiditas lain. Pada gambar 4.3 pada item indikasi pasien dirawat inap kelengkapan sebanyak 497 (87\%) formulir ringkasan pulang, lebih besar dari pada yang tidak lengkap yaitu 74 (13\%) formulir ringkasan pulang. Pada item diagnosis sebanyak 541 (95\%) formulir ringkasan pulang dan tidak lengkap sebesar $30 \quad(5 \%)$ formulir ringkasan pulang. Sedangkan pada item komorbiditas lain kelengkapan sebanyak 484 (85\%), dan yang tidak lengkap sebanyak $87(15 \%)$.

\section{Hasil Review pelaporan sesuai penilaian akreditasi standar MIRM 15 elemen 3,4 dan 5 Snars Edisi 1}

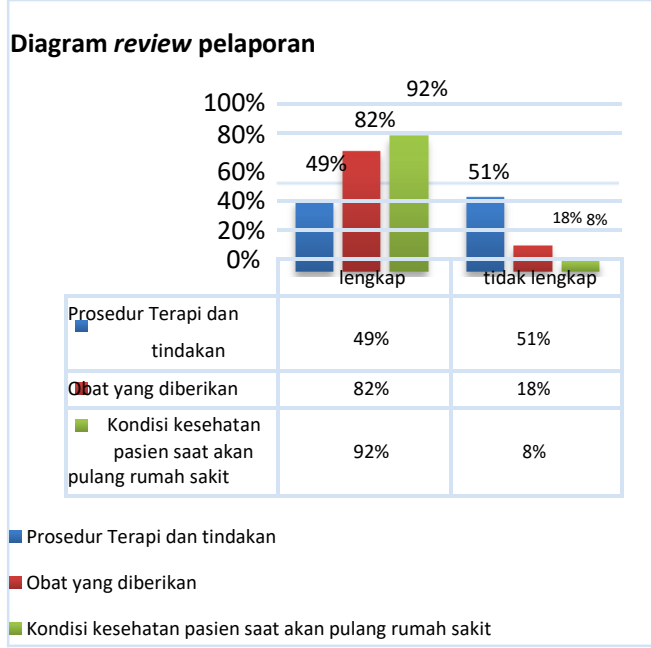

Gambar 4. Hasil review kelengkapan pelaporan sesuai penilaian akreditasi standar MIRM 15 elemen 3,4 dan 5 Snars Edisi 1 di RS Muhammadiyah Selogiri

Komponen review pencatatan elemen 3 MIRM 15 yaitu prosedur terapi dan tindakan yang telah dilakukan, elemen 4 MIRM 15 yaitu Obat yang diberikan, termasuk obat setelah pasien keluar rumah sakit dan elemen 5 yaitu kondisi kesehatan pasien saat akan pulang rumah sakit. Pada gambar 4.4 dapat diketahui tingkat kelengkapan elemen 3 
$280(49 \%)$ dan tidak lengkap yaitu sebesar 291 (51\%) formulir ringkasan pulang. Pada elemen 4 tingkat kelengkapan sebesar $467(82 \%)$ dan tidak lengkap sebesar 104 (18\%) formulir ringkasan pulang. Sedangkan elemen 5 kelengkapan sebesar $526 \quad(92 \%)$ dan ketidaklengkapan sebesar $45(8 \%)$.

\section{Hasil Review pelaporan sesuai penilaian akreditasi standar MIRM 15 elemen 6 Snars Edisi 1}

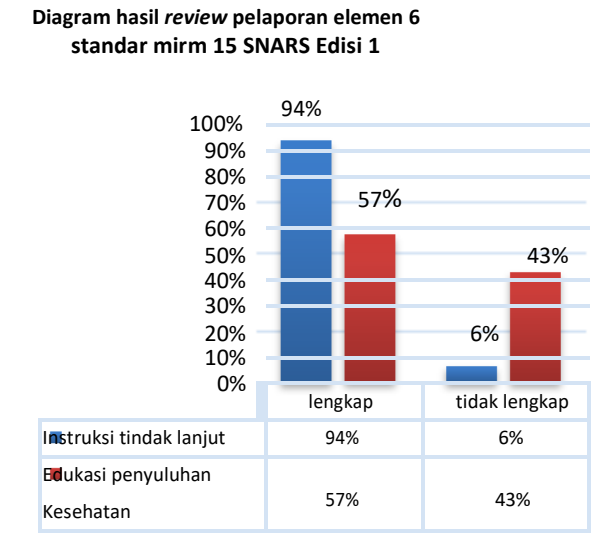

- Instruksi tindak lanjut Edukasi penyuluhan Kesehatan

Gambar 1. Hasil review kelengkapan pelaporan sesuai penilaian akreditasi standar MIRM 15 elemen 6 Snars Edisi 1 di RS Muhammadiyah Selogiri

Komponen review pelaporan elemen 6 MIRM 15 Snars Edisi 1 meliputi instruksi tindak lanjut dan edukasi penyuluhan kesehatan. Pada gambar 4.4 pada item instruksi tindak lanjut kelengkapan sebanyak 534 (94\%) formulir ringkasan pulang, lebih besar dari pada yang tidak lengkap yaitu 37 (6\%) formulir ringkasan pulang. Pada item edukasi penyuluhan kesehatan sebanyak 327 (57\%) formulir ringkasan pulang, lebih dan yang tidak lengkap yaitu 244 (43\%) formulir ringkasan pulang.

Adapun faktor yang menyebabkan ketidaklengkapan formulir ringkasan pulang di Rumah Sakit Muhammadiyah Selogiri Wonogiri berdasarkan review pelaporan antara lain kurangnya kesadaran petugas tentang pentingnya kelengkapan, seperti saat pengisian prosedur terapi dan tindakan yang dikerjakan yang termasuk dalam penilaian akreditasi standar MIRM 15 elemen 3, saat petugas akan meminta kelengkapan kepada DPJP, dokter yang bersangkutan sudah meninggalkan rumah sakit, beban kerja, banyaknya pasien membuat petugas kekurangan waktu dalam melengkapi dokumen rekam medis.
Hasil prensentase kelengkapan formulir ringkasan pulang bulan Februari tahun 2020 di RS Muhammadiyah Selogiri.

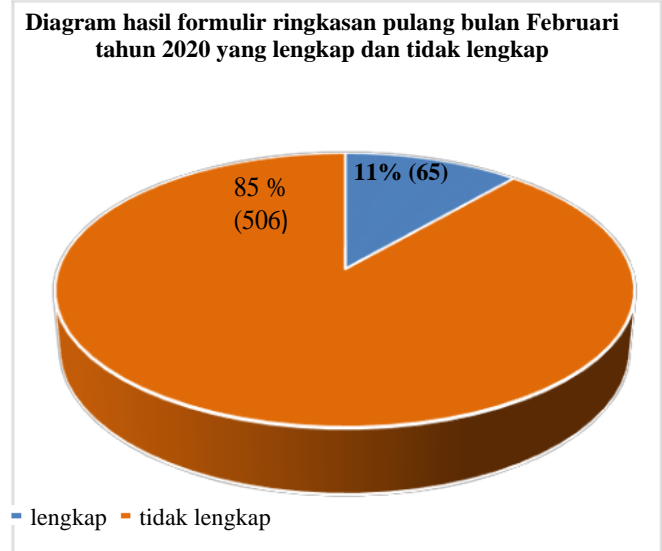

Gambar 6. Hasil Presentase Kelengkapan formulir ringkasan pulang bulan Februari tahun 2020 di RS Muhammadiyah Selogiri

Berdasarkan hasil analisa kelengkapan dan pengisian formulir Rekam Medis ringkasan pulang bulan

Februari tahun 2020 tingkat kelengkapan sebesar $65 \quad(11 \%)$ dan angka ketidaklengkapan sebesar 506 (88\%) formulir rekam medis ringkasan pulang.

\section{PEMBAHASAN}

\section{Review Idetifikasi}

Berdasarkan hasil penelitian diketahui bahwa kelengkapan formulir ringkasan pulang bulan Februari tahun 2020 di Rumah Sakit Muhammadiyah Selogiri Wonogiri berdasarkan review identitas pasien yaitu $100 \%$. Review identifikasi sudah sesuai dengan standar yang ditetapkan oleh MenKes No. 129 tahun 2008 tentang standar Pelayanan

Minimal Rekam Medik tentang kelengkapan pengisian rekam medik 24 jam setelah selesai pelayanan standar $100 \%$. Kelengkapan formulir tersebut dipengaruhi oleh sudah diterapkannya penggunaan label pasien yang mencakup 
nama, jenis kelamin, umur, alamat, dan status pasien sehinga petugas lebih mudah mengisi bagian identifikasi. Pengisian identifikasi pasien dalam formulir berguna untuk memudahkan petugas dalam membedakan pasien yang satu dengan yang lainnya. Identifikasi pasien dengan benar juga telah sesuai dengan standar pemenuhuan penilaian elemen yang ditetapkan oleh KARS (2017), karena termasuk dalam pemenuhan penilaian standar akreditasi SNARS Edisi 1 sasaran keselamatan pasien (SKP) dimana maksud dan tujuan dari SKP adalah untuk memastikan keselamatan pasien yang akan menerima layanan atau tindakan dan untuk menyelaraskan layanan atau tindakan yang dibutuhkan oleh pasien.

\section{Review Autentifikasi}

Dari hasil penelitian diketahui bahwa kelengkapan formulir ringkasan pulang di Rumah Sakit Muhammadiyah Selogiri Wonogiri berdasarkan review autentifikasi kelengkapan mencapai $79 \%$ atau 453 formulir. Review autentifikasi belum sesuai dengan standar yang ditetapkan oleh MenKes No. 129 tahun 2008 tentang standar Pelayanan Minimal Rekam Medik tentang kelengkapan pengisian rekam medik 24 jam setelah selesai pelayanan dengan standar $100 \%$. Ketidaklengkapan formulir tersebut dipengaruhi oleh paraf dan nama Dokter atau paraf nama pasien/keluarga yang sering tidak terisi atau salah satu tidak terisi. Hal tersebut juga belum sesuai dengan teori dari Sudra (2014) bahwa dalam pengisian rekam medis berlaku prinsip bahwa setiap isian harus jelas penanggung jawabnya, kejelasan penanggung jawab ini diwujudkan dengan pencantumkan nama terang (lengkap) dan tanda tangan. Dari hasil hasil wawancara diketahui salah satu faktor ketidaklengkapan pada review autentifikasi salah satunya adalah banyaknya pasien sehingga petugas sering lupa memintakan tanda tangan baik kepada pasien/keluarga dan DPJP.

Hal ini juga didukung dalam penelitian Mahawati,dkk (2019) bahwa diperlukan evaluasi dan sosialisasi lebih intensif kepada semua dokter, perawat maupun penunjang medis guna mendukung pemenuhan aspek autentifikasi dokumen rekam medis sehingga pendokumentasian berkas rekam medis menjadi lebih baik lagi.

\section{Review Pencatatan}

Dari hasil penelitian diketahui bahwa pengisian formulir ringkasan pulang bulan Februari tahun 2020 di rumah sakit Muhammadiyah Selogiri Wonogiri berdasarkan review pencatatan sebesar 414 $(71 \%)$ formulir ringkasan pulang. Hal tersebut belum sesuai dengan ketetapan dari MenKes No. 129 tahun 2008 tentang standar pelayanan minimal rekam medis tentang kelengkapan pengisian rekam medik 24 jam setelah selesai pelayanan dengan standar $100 \%$. Dari hasil wawancara diketahui salah satu faktor yang menyebabkan pencatatan tidak baik pada formulir rekam medis di Rumah Sakit Muhammadiyah Selogiri Wonogiri berdasarkan review pencatatan yaitu karena ketidakjelasan dalam menuliskan diagnosa dan tindakan serta banyak coretan yang tidak disertai paraf baik dokter maupun petugas lainnya hal tersebut tidak sesuai menurut PERMENKES No. 269/PER/III/2008 tentang penyelengaraan rekam medis bab III pasal 5 ayat (6) bahwa pembetulan hanya dapat dilakukan dengan cara pencoretan tanpa menghilangkan catatan yang dibetulkan dan dibubuhi paraf dokter, dokter gigi atau tenaga kesehatan tertentu yang bersangkutan.

\section{Review Pelaporan.}

Berdasarkan hasil penelitian diketahui bahwa kelengkapan formulir ringkasan pulang bulan Februari tahun 2020 di Rumah Sakit Muhammadiyah Selogiri Wonogiri berdasarkan review pelaporan sesuai dengan elemen penilaian dalam akreditasi SNARS Edisi 1 standar MIRM 15 terdiri dari 6 elemen adalah sebagai berikut :

Pada elemen 1 yaitu riwayat kesehatan, pemeriksaan fisik tingkat kelengkapan sebesar $97 \%$ dan pemeriksaan diagnostik tingkat kelengkapan sebesar $86 \%$. Hasil kelengkappan pada elemen 1 yaitu $86 \%$, Skor pada elemen 1 sesuai dengan elemen penilaian yaitu 10 artinya terpenuhi lengkap dalam SNARS Edisi 1 disebutkan 
rumah sakit dapat memenuhi elemen penilaian tersebut minimal $80 \%$.

Pada elemen 2 tingkat kelengkapan pada masing-masing item yaitu indikasi pasien dirawat inap sebesar 87\%, diagnosis sebesar 94\%, dan komorbiditas lain sebesar $85 \%$, Hasil presentase dari ketiga item elemen 2 yaitu $72 \%$ sesuai dengan elemen penilaian skor penilaian yaitu 5 artinya terpenuhi sebagian dalam SNARS Edisi 1 disebutkan rumah sakit dapat memenuhi elemen penilaian tersebut minimal $20 \%-79 \%$.

Pada elemen 3 yaitu prosedur terapi dan tindakan yang telah dikerjakan kelengkapan sebesar 49\%, sesuai dengan elemen penilaian yaitu Skor 5 artinya terpenuhi sebagian dalam SNARS Edisi 1 disebutkan rumah sakit dapat memenuhi elemen penilaian tersebut antara 20\%-79\%. Ketidaklengkapan disebabkan seringnya dokter hanya mengisi saat dilakukan tindakan operatif saja, sedangkan sesuai petunjuk teknis pengisian formulir ringkasan pulang untuk tindakan tidak operatif tetap harus diisi dengan keterangan pengobatan atau medicamentosa.

Pada elemen 4 yaitu obat yang diberikan, termasuk obat setelah pasien keluar rumah sakit tingkat kelengkapan sebesar $82 \%$, sesuai dengan elemen penilaian skor penilaian yaitu 10 artinya terpenuhi lengkap dalam SNARS Edisi 1 disebutkan rumah sakit dapat memenuhi elemen penilaian tersebut minimal $80 \%$. Pada elemen 5 yaitu kondisi kesehatan pasien saat akan pulang rumah sakit tingkat kelengkapan sebesar 92\%, sesuai dengan elemen penilaian skor penilaian yaitu 10 artinya terpenuhi lengkap dalam SNARS Edisi 1 disebutkan rumah sakit dapat memenuhi elemen penilaian tersebut minimal 80\%. Pada elemen 6 tingkat kelengkapan masing-masing item yaitu instruksi tindak lanjut sebesar 94\%, edukasi penyuluhan kesehatan sebesar 57\%. Hasil presentase dari kedua item yaitu sebesar 55\%, sesuai dengan elemen penilaian yaitu skor 5 artinya terpenuhi sebagian dalam SNARS Edisi 1 disebutkan rumah sakit dapat memenuhi elemen penilaian tersebut antara 20\%-79\%. Ketidaklengkapan disebabkan pada item edukasi penyuluhan kesehatan, perawat lupa tidak mencetang atau tanda sesuai simbol sessuai SOP pada kolom yang tersedia, ini menyebabkan pasien saat keluar dari rumah sakit tidak paham bagaimana perawatan yang akan dilakukan saat dirumah, karena ringkasan pulang juga akan dibawa pulang oleh pasien.

Dengan tidak baiknya dalam pengisian formulir ringkasan pulang dapat diketahu bahwa hal tersebut dapat kan mempengaruhi hasil penilaian

akreditasi. Dalam penelitian Mangentang (2015) dijelaskan bahwa kelengkapan pengisian ringkasan pulang merupakan indikator kepatuhan dokter untuk melengkapi ringkasan pulang.

\section{Hasil Prensentase Kelengkapan Formulir Ringkasan Pulang.}

Berdasarkan hasil penelitian diketahui bahwa kelengkapan formulir ringkasan pulang bulan Februari 2020 di rumah sakit Muhammadiyah Selogiri Wonogiri sebanyak 571 dokumen rekam medis tingkat kelengkapan sebesar $65(11 \%)$ dan angka ketidaklengkapan 506 (89\%). Tingkat kelengkapan formulir ringkasan pulang pada bulan Februari di RS Muhammadiyahh Selogiri masih belum sesuai dengan standar karena menurut MenKes No. 129 tahun 2008 tentang standar Pelayanan Minimal Rekam Medik tentang kelengkapan pengisian rekam medik 24 jam setelah selesai pelayanan dengan standar yaitu $100 \%$. Dari hasil penelitian, review identifikasi $100 \%$. Sudah sesuai menurut Hatta $(2008)$ pada review identifikasi standar $100 \%$, dan dijelaskan dimana nama lengkap pasien harus terdiri dari nama sendiri dan nama keluarga (suami/ayah/marga), diikuti tanda koma dan nama sendiri. Pengisian identifikasi pasien dalam formulir berguna untuk memudahkan petugas dalam membedakan pasien yang satu dengan yang lainnya.

Sedangkan ketidaklengkapan dalam pengisian identifikasi pasien dapat mengakibatkan kesalahan dalam pengidentifikasian pasien dan terjadi insiden keselamatan pasien.

Untuk pengisian review autentifikasi Menurut Sudra R.I (2014) dalam pengisian rekam medis berlaku prinsip bahwa setiap isian harus jelas penanggungjawabnya, kejelasan penanggung jawab ini diwujudkan dengan pencantumkan nama 
terang (lengkap) dan tanda tangan dokter maupun pasien/keluarga.

Pada review pencatatan masih ditemukan coretan pada formulir tanpa paraf, hal tersebut belum sesuia dengan PERMENKES No. 269/PER/III/2008 tentang penyelengaraan rekam medis bab III pasal 5 ayat (6) bahwa pembetulan sebagaimana disebutkan pada ayat (5) hanya dapat dilakukan dengan cara pencoretan tanpa menghilangkan catatan yang dibetulkan dan dibubuhi paraf dokter, dokter gigi atau tenaga kesehatan tertentu yang bersangkutan.

Pada pengisian review pelaporan menurut Sudra R.I (2014) penting untuk diperhatikan bahwa dalam setiap pencatatan pelaporan harus mencantumkan tanggal dan jamnya. Pada lembar ringkasan pulang review pelaporan meliputi uraian yang tercantum dalam elemen penilaian akreditasi SNARS Edisi1 standar MIRM 15 yang terdiri dari 6 elemen. Dari 6 elemen diketahui skor elemen penilaian menurut SNARS Edisi 1 masih belum seluruhnya mendapatkan skor 10 yang artinya terpenuhi lengkap. Dari hasil wawancara dilakukan triangulasi sumber kepada 2 perwat selaku petugas yang berkewajiban mengingatkan DPJP untuk meengkapi formulir ringkasan pulang di RS Muhammadiyah Selogiri beberapa faktor yang menyebabkan ketidaklengkapan diantaranya adalah beban kerja atau banyaknya pasien sehingga petugas tidak memperhatikan kelengkapan formulir sebelum dokumen dikembalikan ke unit rekam medis, serta adanya pasien yang meminta APS atau pasien yang meninggal saat dokter tidak berada di RS menyebabkan dokumen rekam medis belum terisi dan kemudian dikembalikan ke unit rekam medis dalam keadaan belum lengkap. Hal ini didukung dalam penelitian Mahawati dkk (2019) bahwa setiap pasien memiliki dokumen rekam medis yang seharusnya memiliki kualitas bagus dalam kelengkapan dan pencatatannya, baik dalam bentuk kertas maupun elektronik yang merupakan sumber informasi utama mengenai proses asuhan dan perkembangan pasien sehingga menjadi media komunikasi yang penting.

\section{SIMPULAN}

Hasil review kelengkapan formulir ringkasan pulang bulan Februari tahun

2020 sebagai berikut :
1. Kelengkapan pada review identifikasi sudah sesuai standar yaitu $100 \%$.

2. Kelengkapan pada review autentifikasi belum sesuai standar, tingkat kelengkapan sebayak 464 formulir $(81 \%)$, belum sesuai standar.

3. review pencatatan kelengkapan sebanyak 367 formulir (64\%) dan belum sesuai standar.

4. Hasil review pelaporan sesuai penilaian akreditasi SNARS Edisi 1 standar MIRM 15

1) Elemen 1 kelengkapan sebanyak 555 formulir (97\%) pada item riwayat kesehatan, pemeriksaan fisik dan pada item pemeriksaan

diagnostik sebanyak 492 formulir (86\%) dengan hasil

kelengkapan 488 formulir (86\%), sesuai elemen penilaian akreditassi SNARS Edisi 1 skor 10 yaitu terpenuhi lengkap.

2)

Elemen 2 kelengkapan pada item indikasi pasien dirawat inap, 497 formulir (87\%), item diagnosis 541 (95\%) dan item komobiditas lain 484 formulir (85\%) dengan hasil kelengkapan pada elemen 2 yaitu 410 formulir (72\%), sesuai elemen penilaian akreditassi SNARS Edisi 1 skor 5 yaitu terpenuhi sebagian.

3) Elemen 3 yaitu item prosedur terapi dan tindakan yang telah dilaksanakan tingkat kelengkapan sebanyak 280 (49\%). sesuai elemen penilaian akreditassi SNARS Edisi 1 skor 5 yaitu terpenuhi sebagian.

4) Elemen 4 yaitu item obat yang diberikan, termasuk obat setelah pasien keluar rumah sakit diberikan, tingkat kelengkapan sebesar 82\% (467). Sesuai elemen penilaian akreditasi SNARS Edisi 1 skor 10 yaitu terpenuhi lengkap.

5) Elemen 5 yaitu item kondisi kesehatan pasien saat akan pulang rumah sakit, sebesar 92\%. sesuai elemen penilaian akreditassi SNARS Edisi 1 skor 10 yaitu terpenuhi lengkap

6) Elemen 6 pada item instruksi

tindak lanjut kelengkapan sebanyak 534 (94\%), pada item edukasi penyuluhan 
kesehatan sebanyak 329 (58\%) . Hasil presentase dari kedua item yaitu sebesar 55\%. Sesuai dengan elemen penilaian SNARS Edisi 1 yaitu skor 5 artinya terpenuhi sebagian.

\section{DAFTAR PUSTAKA}

Harjanti and Rizka, K., 2019. The Accuracy of Abbreviation Symbol Usage toward Inpatient Medical Record Documents with Schizophrenia Diagnosis Ketepatan Penggunaan Singkatan Dan Simbol Pada Dokumen Rekam Medis Rawat Inap Diagnosis Schizophrenia', Rekam Medis dan Informasi Kesehatan, 2.

Hatta, G. R., 2010. Pedoman Manajemen Informasi Kesehatan disarana pelayanan kesehatan. Edited by G. R. Hatta. Jakarta: UI Press.

KARS., 2017. Efektif 1 Januari 2018', Standar Nasional Akreditasi Rumah Sakit, 1, p. 421.

Kusbaryanto., 2010. Peningkatan Mutu Rumah Sakit dengan Akreditasi Increasing Hospital Quality by Accreditation', Mutiara Medika, 10 No.1 :, pp. 86-89.

Mahawati, E. et al., 2019. Studi kasus di rumah sakit tipe $\mathrm{C}$ dan tipe $\mathrm{B}$ : Analisis identifikasi dan autentikasi dokumen rekam medis berbasis

SNARS', VISIKES: Jurnal Kesehatan Masyarakat, 18, pp. 130-145.

Mangentang, F. R., 2015. Kelengkapan Resume Medis dan Kesesuaian Penulisan Diagnosis Berdasarkan ICD-10 Sebelum dan Sesudah JKN di RSU Bahteramas', 1(44), pp. 159168.

\section{Menkes RI, 2008. Keputusan Menteri Kesehatan RI Nomor 129/MENKES/SK/II/2008 tentang Standar Pelayanan Minimal Rumah Sakit.}

Menkes RI. 2008. Peraturan Menteri Kesehatan Republik Indonesia

No. 56/Menkes/Per/2014, tentang Klasifikasi dan Perizinan Rumah Sakit.
Menkes RI, 2008. Peraturan Menteri Kesehatan Republik Indonesia No. 269/Menkes/Per/III/2008, tentang Rekam Medis.

Menkes RI, 2017. Peraturan Menteri Kesehatan Republik Indonesia No. 34/Menkes/Per/2017, tentang Akreditasi Rumah Sakit.

Menkes RI, 2012. Peraturan Menteri Kesehatan Republik Indonesia No. 012/Menkes/Per/2012, tentang Akreditasi Rumah Sakit.

Menkes RI, 2013. Peraturan Menteri Kesehatan Republik Indonesia No. 82/Menkes/Per/2013, tentang Manajemen Rumah Sakit.

Sudra, R. I., 2013. Rekam Medis. Tangerang Selatan: Universitas Terbuka.

Republik Indonesia, 2009. UndangUndang RI Nomor 44 Tahun 2009 tentang Rumah Sakit.

Republik Indonesia, 2009. UndangUndang RI Nomor 36 Tahun 2009 tentang Kesehatan. 
Jurnal Manajemen Informasi dan Administrasi Kesehatan (JMIAK)

ISSN: 2621-6612 | Email:jmiakmedrec@gmail.com

Volume 03 Nomor 02 November 2020 Halaman 12-19 